\title{
Increased Public Understanding of the Agreement on Fish Management in Sungai Paku Village Kampar Kiri Sub-District Kampar District
}

\author{
Peningkatan Pemahaman Publik terhadap Perjanjian \\ Pengelolaan Ikan di Desa Sungai Paku Kampar Kiri \\ Kecamatan Kampar
}

\author{
Yeni Triana \\ University Lancang Kuning Pekanbaru \\ Email: yeni_hukum@yahoo.com
}

\begin{abstract}
The purpose of this service to the community is to analyze the implementation of the contents of the agreement agreed on by both parties in Sungai Paku Village, Kampar Kiri Subdistrict, Kampar Regency, in the aspect of legal consequences caused not to implement the agreement of default, in the perspective of business law. The target of the settlement of this defaulting case is very important in the business world for business competition to improve the standard of living of the Sungai Paku Village community, in particular and, hence the follow-up of the results of this service, may be useful for the service team and outside parties related to small and medium enterprises regarding this default is in the form of material articles on lecture studies for students and allows at the same time to do community service. The method of implementation is sociological law research which is more focused on the problems that arise and for that the researcher focuses on the discussion of statutory provisions and see how law is practiced in society. In the discussion of service found that the problems faced by the community, it is necessary to solve the problem by providing a clear picture to the community.
\end{abstract}

Keywords: Agreement, Default, Management.

\section{INTRODUCTION}

The community in Sungai Paku Village, Kampar Kiri Subdistrict, is a dynamic community, where most of the residents have jobs either as workers in the government sector, plantation companies, agriculture or independent business activities, such as fish ponds, because this is possible, Sungai Paku Village is not located. far from the hustle and bustle of City, Subdistrict, thus triggering its citizens to carry out positive activities to support their daily needs. Therefore, as a village that is close to the city center, the people who live in this village have a variety of work backgrounds. One of the business activities that residents are interested in, is doing side jobs apart from having a permanent job, such as small-scale businesses, households. Generally, the people of Sungai Paku Village have a business to support their daily needs, where they often have legal relations with other parties, such as financial institutions, both banks and non-banks, as well as other parties as partners. This is done both to start a business, as well as to expand the business by increasing business capital, as well as expanding the partnership network, such as fish ponds, because Sungai Paku Village has a large enough dam to make a fish pond business. The people of Sungai Paku Village who own the business certainly want their business activities to develop and run smoothly. However, sometimes the business that is carried out experiences various kinds of obstacles, this is something that usually occurs in business activities, it does not always run as expected smoothly and develops, such as problems, both arising from them 
themselves, and other parties who hold legal relationship, not keeping promises that have been agreed upon.

For example the problems that arise from themselves, namely not being able to pay off their obligation to pay installment for a vehicle as a means of smoothing their business, while other parties as partners also do the same, sometimes, they do not keep their agreed promises to pay off their debts, when taking fish. This is a problem that results in disputes between the two parties, who do not understand the legal aspects, especially the law of the agreement, which results in disputes between the two parties, which sometimes results in unexpected losses by both parties. Therefore, it should be before deciding. To carry out a legal relationship, especially regarding an agreement, the parties should pay attention to the factors that can influence the implementation of an agreement itself. (Abdul R. Salinan, et al, 2010). Basically, business activities are business fields with (almost) unlimited reach, all opportunities can be processed into business opportunities. From the legal aspect, those who will carry out business activities must choose the form of business that is available based on the existing legal framework. (Abdul R. Salinan, et al, 2010). In general, this has an influence on the position of the parties as legal subjects and with all the legal consequences (Tri Budiono, 2010). For the people of Sungai Paku Village, an understanding of legal norms is important so that the purpose of running efforts to create welfare can be achieved (Salim HS, 2007). Selection of business partners needs to be done with careful consideration to prevent unwanted things from happening in the future. With a clear form according to the law, it can be expected that the company will be able to firmly determine the steps that must be taken in order to achieve the desired goals. (M. Fuad, Christine H, Lurlela, Sugiarto, Paulus, Y.E.F, 2000). Selection of business partners must be adjusted to the available capital and the objectives of the implementation itself. For example, when entering into a legal relationship, in the form of an agreement between the two parties, where individual businesses generally have small to medium-scale activities, so that sometimes their individual businesses lack the trust of capital providers, and as a result, the possibility of obtaining funds is also limited. On the other hand, companies that have large capital usually have the right choice and use of funds. In general, the people of Sungai Paku Village, Kampar Kiri District, Kampar Regency do not understand default, in the legal aspects of the agreement, meanwhile, they are always faced with problems of legal relations in the agreement, with all the legal consequences, including the phases of entering into an agreement. the parties who entered into the agreement, all of which include the legal consequences resulting from the implementation of the nonfulfilling agreement, as well as how the dispute is resolved. is an important thing when they run their business.

\section{RESEARCH METHODS}

This form of method of implementing community service activities is Sungai Sail Village, Kampar Kiri District, Kampar Regency, this is the lecture and question and answer method in order to provide knowledge and information to all participants who take part in this service activity, so that they can understand the implementation of agreements, defaults and consequences. law resulting from not implementing the contents of the agreement. The series of activities carried out in the context of community service use two methods, namely: 1 . Lecture or counseling. In this method the speaker or extension agent delivers material about the agreement, defaults and the resulting legal consequences of not carrying out the contents of the agreement. In this stage, participants are free to ask and answer questions with the speaker. The details of this method are the explanation of the legal aspects of the contract law and default. 2 . Interactive dialogue, in this stage participants are positioned as subjects who can provide comments related to problems arising from the agreement. This dialogue is a form of disclosing the contents of the problems faced by participants in order to obtain solutions and settlement of disputes arising from agreements and the expected solutions.

Work Procedures. In this activity, work procedures are carried out in several stages, namely, the first stage of preparation. This preparation is focused on preparing all the equipment needed to carry out this activity, studying literature and coordinating with related agencies to carry out activities. Second, site visits to determine the location (location) of 
extension activities. Third, designing the Legal Counseling module. This stage prepares the material that will be displayed in the activity. The module is reproduced by the number of participants involved in the activity. Fourth, the implementation of legal counseling was carried out by the Implementing Team from the Law Faculty of Lancang Kuning University and material on contract law from a business law perspective.

Partner Participation. The implementation of these service activities can be carried out, so it is necessary to have participation from related agencies and communities in Sungai Paku Village, Kampar Kiri District, Kampar Regency, in particular, as well as other communities outside Sungai Paku Village, including: 1) In determining this location is determined by; Sekdes Sungai Paku, Head of Sungai Paku Administration, Kampar Kiri District, Kampar Regency. 2) The community of Sungai Paku Village, Kampar Kiri Subdistrict, Kampar Regency, is willing to attend counseling about defaults in the agreement law from beginning to end.

Evaluation Techniques. This service activity is carried out an evaluation, where in order to know the success of this service activity, an evaluation is carried out after this activity is carried out. The evaluation is carried out after providing material provision to the community. Where the technique used in this evaluation is by identifying the number of participants and at the same time giving questionnaires to participants related to the activity material, both before and after the service activity is carried out. As for the benchmarks for the success of this activity: 1) The realization of cooperation between the implementers of the activity and the local community, 2) The number of participants who attended is at least $50 \%$ of the invitees, 3) There is a two-way interaction in activities between speakers and participants, 4) Increased understanding of the participants related to the material presented.

\section{RESULT}

The implementation of this activity has provided an increase in the knowledge of the target audience, so it is very useful for the audience if they want to collaborate and expand business networks by collaborating with other parties, so in this case it is very important to understand a contract and the legal consequences that arise if there is a disagreement. in understanding contract performance. Therefore, the problem faced by the target audience before giving the material is that fish management business actors and their partners have very minimal knowledge of contracts, even some fish pond managers do not understand what a contract is and its legal consequences, even though they often commit actions. the contract. Based on the results obtained from this activity, the participants have felt the benefits, namely getting additional knowledge and understanding of contracts in general, and the legal consequences in particular.

The participants even asked for the extension to be held again because considering the limited time for the implementation of this service, this is of course a very good appreciation for the relationship between the two parties, namely the service team feels very grateful that the partners are very enthusiastic about the knowledge of this contract, by because of that the service team will respond to these requests and will continue to establish good cooperation between the two parties in the future. This was concluded by the community service team after comparing the results of the pre-test and post-test by submitting a questionnaire before and after giving the material.

Before giving the initial test, many of the target audiences or participants did not know and understand the meaning of the contract in general and its legal consequences. After community service has been carried out by providing appropriate material, the target audience is generally able to answer correctly the questions in the questionnaire that are asked after the implementation of the activity. Thus, this community service activity can be said to have been successful with the comparison of the results of the pre-test and post-test results by submitting a questionnaire before and after giving material to the target audience.

The implementation of this community service activity can be said that there are no obstacles, because the themes raised are quite interesting and relevant to the information or knowledge needed by the participants.

This is because there are among the participants who have academic potential, making it easy to communicate and interact. However, behind this success it is also not spared from the 
obstacles faced when implementing it in the field technically but it does not become a significant problem, namely the technical implementation time, for example because partners often collaborate outside the region so that the implementation time is divided into two implementation sessions, namely there is a partner group. whose implementation time is held at night, because in the morning they cannot attend due to the cooperation of partners outside the region which is quite time-consuming, so that the time that has been determined is shifted at night, but this does not reduce the principle of this community service, the implementing team keep carrying out its duties by providing time to provide the material.

This activity succeeded in increasing understanding for business actors and their partners.

Indications of success can be seen in their enthusiasm in asking critical questions in accordance with the experiences experienced by business actors, namely they ask how to deal with contracts submitted unilaterally by suppliers of these fish management partners who were originally located outside the region, such as , West Sumatra, Jambi, and Palembang, they are only offered an existing contract and its legal consequences, this is what they often face with their partners / contractors (Sadarlis, Chair of the Fish Management Group, Monday, 1.00 WIB in Sungai Paku Village). The activity was carried out in two sessions, namely at $19.30-21.30$ WIB and the second session at $14.00-17.30$ WIB at the Sungai Paku Village Office, Subdistrict Kampar Kiri District Kampar. This activity was successful with the following benchmarks: 1) The number of participants who attended was 27 people in the first session from which 40 people were invited. 2) Business actors and partners in the second session who attended were 15 out of 20 of those invited who were partners of fish managers. 3) Cooperation between participants and the Unilak Faculty of Law Extension Team went smoothly. 4) Extension participants enthusiastically participate in all series of outreach, from material presentation to question and answer sessions.

\section{DISCUSSION}

\section{Target Audience Knowledge}

The implementation of this service to the community, especially for the target audience for fish managers, provides very important benefits for the target audience and partners, this is evident after being given the material presentation, the target audience is so enthusiastic in asking various questions, one of the most important questions according to them is how to provide solutions legally, if they enter into a contract verbally without evidence of a written contract between the two parties, while one of the parties is outside the country of Indonesia, this is what needs legal settlement, because according to them all this time they have collaborated with various parties outside the region. oral contract. This problem is very interesting to be discussed in the question and answer discussion.

Implementation of extension using lectures and dialogue methods. The first session used the lecture method. The speaker delivers the material/material. Participants listen to the material presented by the speaker. However, before participants are given material, participants are given a questionnaire with several questions about the meaning of a contract in general, the types of contracts, the validity of a contract, and the difference between a contract and a promise, as well as the principles in the contract, the legal consequences of the contract. the definition of achievement, default, and so on based on the Agreement Law set out in the Civil Code. The correct answer to the questionnaire is in the material presented by the speaker. The purpose of the questionnaire at the beginning of the presentation of the material is to measure the knowledge of the participants.

Evaluation of the extension using the questionnaire/questionnaire method totaling twenty. The extension team distributed 40 questionnaires to participants and participants answered the questions in the questionnaire by circling the correct answers. The questionnaire was divided into two times, namely before and after the material was delivered. The aim is to determine the increase in participants' understanding of the material before and after it is delivered. Their understanding can be seen in each questionnaire question as well as the participants' answers.

The results of the evaluation of participant knowledge begin with questions about, whether a promise is the same as an agreement or contract, the definition of a contract, the meaning of a 
nominaate contract, the meaning of an innominaate contract, the legal terms of a contract, the principles in the contract, the legal consequences of the contract, the definition of achievement, the default according to Civil Code law.

This situation was concluded by the community service team after comparing the results of the initial test (pre test) and the final test (post test) by submitting a questionnaire before and after giving the material as can be seen in the evaluation of the extension using the questionnaire/questionnaire method totaling 40 (forty). The extension team distributed 40 (forty) participants and participants answered the questions in the questionnaire by circling the correct answers. The questionnaire was divided into two times, namely before and after the material was delivered. The aim is to determine the increase in participants' understanding of the material before and after it is delivered. The first questionnaire begins with a question about whether the meaning of a promise is the same as the meaning of an agreement or contract. The choice of answers to these questions is (A) not the same, (B) the same, only $25 \%$ (twenty five percent) of the participants answered incorrectly as can be seen in the following:

Table 5.1 Is the definition of a promise the same as an agreement or contract No Alternative Answers Number of Answers\% A Equals 825 6B Not the same 3275 Total 40100 Only a few participants thought that the meaning of a promise was the same as the meaning of an agreement or contract, this can be seen from the results of the questionnaire where nearly $25 \%$ (seventy five percent) of participants answered option A. The correct answer to this question is B. The second question is to measure the participants' knowledge about whether a contract is the same as a contract. The answer choices to this question are (A) Not the same, (B) the same. The correct answer is (B), namely the meaning of the agreement with the contract is the same. More than half of the participants who answered correctly to the second question, seen from the results of the questionnaire, 56\% (fifty six percent) of participants who answered that the Understanding of Agreement with Contract is the Same. The next question is about the legal terms of an agreement. The answer options for this question are (A) the existence of an agreement, proficiency, certain objects, lawful causes, and (B) the existence of a stamp, signature, old age, notary public. The correct answer is (A) there is an agreement, proficiency, certain objects, lawful causes, only 31\% (thirty one percent) of the participants answered correctly. As many as 69\% (sixty percent) of the participants thought that the conditions for the validity of an agreement or contract were a stamp, signature, old age, notary public, the correct answer should be an agreement, competence, certain object, lawful cause, there is an agreement, capable, certain object, halal causa. The next question from the questionnaire distributed to the participants concerns the legal consequences of not implementing the contents of the agreement. The answer choices are (A) Illegal, and (B) Default. The correct answer is (B) default, only $37 \%$ (twenty seven percent) of the participants answered correctly. As for the parties who do not carry out the contents of the agreement, they will be sued, namely by giving Default. The last question listed in the questionnaire is regarding the types of sanctions against default in the agreement. The answer provided for this question (A) in prison, (B) Compensation, as many as $63 \%$ (sixty three percent) of the participants answered correctly. Types of default sanctions in compensation for parties who do not carry out the contents of the agreement agreed upon by both parties. Overall, the level of participants' knowledge and understanding of the agreement and all legal consequences that it violates in the agreement is still low, there are still many participants who do not understand the importance of knowing the rights and obligations in the agreement that have been agreed upon by them. The questions with the highest percentage of correct answers were not more than $69 \%$ (sixty percent) for questionnaires number 4 (four) and 5 (five), and the highest incorrect answers were $75 \%$ (seventy five percent) for questionnaire number 1 (one)Understanding of participants in community service activities after legal counseling. Increased knowledge of activity participants about increasing community understanding of the fish management agreement in Sungai Paku Village, Kampar Kiri District, Kampar Regency, after legal counseling. The questionnaire given before legal counseling was given back to the activity participants to measure the differences before and after the activity was carried out.

After the provision of material and counseling was carried out, there was an increase in the participants' knowledge, this was because the participants listened well to the material provided 
at the time of counseling so that generally participants answered the questionnaire. It can be seen that the choice of the target audience generally chooses the answer they already know, except for the 3rd question, which is about whether the promise is the same as the contract, only 5 people because they think the promise is an agreement to be the same as the contract, while if in the agreement law it is not the same because the promise has no effect the law or $(28 \%)$ participants who have answered already know. Based on the participants' answers above, it can be concluded that before the implementation of the activities, all participants did not know and understand about the contract understanding program and its legal consequences, as well as the settlement if there was default according to the Civil Code. On the other hand, after giving the material there was an increase in the knowledge of the target audience. indicates that the participants' understanding reaches more than $80 \%$ (eighty percent) of the 5 (five) questionnaire questions. The highest correct answer is $88 \%$ (eighty percent) on questionnaire questions 4 (four) and 5 (five), while the lowest correct answer is 63\% (sixty three percent) on questionnaire questions 1 (one).

Achievement of activity targets

The solutions offered in this activity can be used as a basis for solving the problems faced by the parties in fish management in Sungai Paku Village: 1) With regard to partner problems related to the lack of partner knowledge about the importance of paying attention to related agreements regarding fish management agreements in accordance with what has been agreed upon by both parties. 2) With regard to partner problems related to a lack of understanding of all legal consequences of not carrying out the contents of the agreed agreement. The implementation of this service activity has achieved the targets planned in point 1 to point 2 above. In point 1, overcoming partners' ignorance, legal counseling activities have been carried out regarding the importance of paying attention to the related agreement regarding the fish management agreement in Sungai Paku Village. the rights and obligations of both parties. In point 2, it is related to the partner's lack of understanding regarding all the legal consequences of not carrying out the contents of the agreement agreed upon by both parties. The presenter has conducted dialogue with partners by providing correct knowledge about common agreement issues and all legal consequences related to the agreement, particularly regarding fish management in Sungai Paku Village. In addition, the speaker also conveyed about the settlement of not implementing the contents of the agreement agreed by both parties.

Outputs Achieved in Community Service Activities

Community service regarding increasing community understanding of the fish management agreement in Sungai Paku Village, Subdistrict Kampar Kiri District Kampar, responded positively by the target audience. The enthusiasm of the target audience is quite large. It can be seen that quite a number of people raised questions about the agreement, customers against not complying with the contents of the agreement, how to make the correct agreement, the legal consequences of not implementing the agreement.

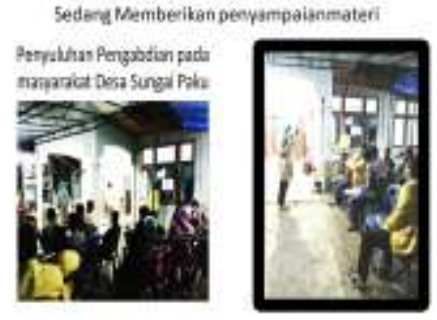

Picture 1

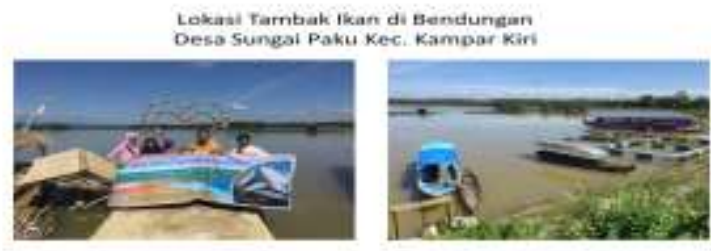

Picture 2

\section{CONCLUSION}

The problem faced by the target audience before giving the materials was that they did not understand the agreement they had made, so that fish managers were often disadvantaged, because they did not understand the general agreement. As well as the meaning of a promise 
with an agreement or contract, the difference between an agreement or contract with a promise, the validity of a contract, and the principles of contracting, as well as the legal consequences that arise in the execution of the contract and so on. The results of the implementation of this activity have provided an increase in the knowledge of the target audience so that it will be very useful for the target audience if they want to collaborate and expand business networks by collaborating with other parties, so in this case it is very important to understand a contract and the legal consequences if it occurs disagreement in understanding the implementation of the contract, especially the fish management agreement in Sungai Paku Village, Kampar Kiri District, Kampar Regency We recommend that community service with this theme can be continued with consultation and guidance to audiences who enter into cooperation contracts with other parties or partners in fish management in Sungai Paku Village, Subdistrict Kampar Kiri, District Kampar. In addition, community service with this theme will be developed into training in contractmaking techniques where the target party itself wants training in contract-making techniques, which originally asked the service team to carry out a service at a later stage. This is very appreciated by the service team to continue the next phase of service. So that there is a good collaboration between the service team and the fish management partner in Sungai Paku Village, because according to the community service partner's admission, it is very necessary considering that the duration of time is still not optimal, therefore the partner asked the team to continue the next service.

\section{REFERENCES}

Abdulkadir Muhammad, 2010, Hukum Perdata Indonesia, Bandung, cet. Revisi, PT. Citra Aditya Bakti. 1990, Hukum Perikatan, Bandung, Citra Aditya Bakti, 1990.

Agus Suki Widodo, 2004, Tanggungjawab Para Pihak dalam Pelaksanaan Perjanjian SewaMenyewa Kendaraan Bermotor di Surakarta, Magister Kenotratiatan Universitas Diponegoro Semarang.

Agus Yudha Hernoko, 2014, Hukum Perjanjian Asas Proposional Dalam Kontrak Komersial, Jakarta, cet. Revisi, Kencana.

Ahmadi Miru \& Sakka Pati, 2011, Hukum Perikatan Penjelasan Makna Pasal 1233 sampai 1456 BW, Jakarta, Rajawali Pers.

Handri Raharjo, 2009, Hukum Perjanjian di Indonesia, Jakarta, Pustaka Yustisia.

Herlien Budiono, 2009, Ajaran Umum Hukum Perjanjian, Bandung, PT. Citra Aditya Bakti, Bandung.

2006, Asas Keseimbangan Bagi Hukum Perjanjian Indonesia, Hukum Perjanjian Berlandaskan Asas-Asas Wigati Indonesia, alih bahasa Tristam P. Moeliono, Bandung, Citra AdityaBakti.

2007, Kumpulan Tulisan Hukum Perdata di Bidang Kenotariatan, Bandung Citra Aditya Bakti.

I.G. Rai Widjaya, 2004, Merancang Suatu Kontrak (Contract Drafting),Bandung,cet. 3, Kesaint Blanc.

J. Satrio, 1993, Hukum Jaminan, Hak-Hak Jaminan Kebendaan, Bandung, PT. Citra Aditya Bakti. 1995, Hukum Perikatan, Perikatan Lahir Dari Perjanjian, Buku II, Bandung, Citra

Aditya Bakti.

M.Yahya harahap, 2005, Hukum Acara Perdata, Jakarta, Sinar Grafika.

2005, Aneka Hukum Bisnis, Bandung, Alumnni.

1996, Kitab Undang-Undang Hukum Perdata Buku III Tentang Hukum

Perikatan Dengan Penjelasan, Ed. II, Cet. I,Bandung, Alumni.

Ridwan Khairandy, 2004, Iktikad Baik Dalam Kebebasan Berkontrak, Jakarta, Pascasarjana Universitas Indonesia.

Salim H.S, 2003, Hukum Kontrak, Jakarta, Sinar Grafika.

Suharnoko, 2004 Hukum Perjanjian Teori dan Analisa Kasus, Jakrta, Prenda Media.

Subekti, 2007, Hukum Perjanjian, Jakarta, PT Intermasa.

Wijono Prodjodikoro, 2000, Asas-Asas Hukum Perjanjian, Bandung, Mandar maju, 2000. 
Yahman, 2015, Karakteristik Wanprestasi Dan Tindak Pidana Penipuan, Jakarta, Prenanda Media.

Melda Kamil Ariandno, 2005, Kepentingan Indonesia Dalam Pengelolaan Perikanan Laut Bebas, 2003, Jurna Hukum Internasional, vol. 3 No. 2.

Fatma Muthia Kinanti, 2013, Penyeludupan Ikan Di Wilayah Perbatasan Kalimantan BaratSerawak Sebagai Bentuk Transnational Crime dan Kaitannya Dengan Perjanjian Kerjasama Pengelolaan Perbatasan Indonesia Dan Malaysia, Gloria Yuris Jurnal Hukum Mahasiswa, Vol. 1, No. 2. 